\title{
Aproximaciones a la inquietante extrañeza en la pintura contemporánea: una perspectiva de género
}

\author{
Sheila Rodríguez Cañestroํㅜ Javier Garcerá Ruiz ${ }^{2}$
}

Recibido: 27 de febrero de 2018 / Aceptado: 17 de mayo de 2018

Resumen. En el contexto del arte contemporáneo, cada vez es más frecuente encontrar mujeres artistas nacidas en la segunda mitad del siglo XX que elaboran sus obras desde un lenguaje pictórico construido a través de un esmerado dominio de la técnica y el oficio y que se interesan en representar escenas de una alta tensión narrativa, inquietante y turbadora. En este artículo vamos a partir de tres exposiciones que en torno a estos temas se han organizado a nivel internacional (Nightfall: New tendencies in figurative painting, This side of Paradise y New Black Romanticism) que son un ejemplo más de la escasa representación femenina en este tipo de eventos y que constatan la marginación y el silencio que la historia del arte ha otorgado a la mujer. Como consecuencia de ello, planteamos este artículo desde un posicionamiento crítico feminista que pretende no sólo dar visibilidad a un grupo numeroso de pintoras figurativas sino también reivindicar las diferencias de sus propuestas respecto a las narrativas de los artistas varones incluidos en dichas exposiciones y a los cánones predominantes.

Palabras clave: Pintoras figurativas; feminismo; pintura; arte contemporáneo; siniestro; inquietante; extrañeza; oscuridad; identidad.

\section{[en] Approaches to the uncanny in contemporary painting: a gender perspective}

\begin{abstract}
In the context of contemporary art, it is becaming increasingly common to find female artists born during the second half of the twentieth century who elaborate their works from a pictorical language constructed through a careful mastery of technique and craft and that are interested in representing disturbing high narrative tension scenes. In this article, we are going to start from three exhibitions that have been organized around these themes at an international level (Nightfall: New tendencies in figurative painting, This side of Paradise y New Black Romanticism) which are another example of the under-representation of women in this type of events and that confirm the marginalization and silence that the history of art has given to women. As a consequence, we propose this article from a critical feminist position that aims not only to give visibility to a large group of figurative female painters but also to defend the differences of their proposals regarding the narratives of the male artists included in the previously mentioned exhibitions and the predominant canons.
\end{abstract}

Keywords: Figurative painters; feminism; painting; contemporary art; uncanny; disturbing; strangeness; darkness; identity.

Sumario. 1. Introducción. 2. Contexto. 2.1. Nightfall: New tendencies in figurative painting. 2.2. This side of Paradise. 2.3. New Black Romanticism. 3. Las mujeres que pintan. 3.1. La

1 Universidad de Málaga, Departamento de Arte y Arquitectura sheilarodriguez576@gmail.com

Código ORCID: 0000-0001-9185-6864

2 Universidad de Málaga, Departamento de Arte y Arquitectura javiergarcera@gmail.com Código ORCID: 0000-0001-6636-6863 
crisis interior y el deseo de armonía. 3.2. La mujer como enigma y pesadilla. 3.3. La identidad femenina y lo doméstico. / A modo de conclusión

Cómo citar: Rodríguez Cañestro, S., Garcerá Ruiz, J. (2018) Aproximaciones a la inquietante extrañeza en la pintura contemporánea: una perspectiva de género, en Anales de Historia del Arte $\mathrm{n}^{\circ} 28$ (2018), 113-132.

\section{Introducción}

Si desde las décadas de los sesenta y setenta hemos presenciado en buena parte del arte contemporáneo una creciente tendencia a la desmaterialización del objeto artístico, hay que destacar que en la década actual están apareciendo cada vez más artistas que viven intensamente el proceso de elaboración de la obra, que trabajan sus discursos desde un lenguaje construido sobre un esmerado dominio de la técnica y la manualidad y que, frente a aquellos procesos de minimización, e incluso de eliminación del soporte físico, reivindican el hacer y el oficio como modo de recuperar una narrativa que se apoya en la atracción de la sensualidad de la materia.

Nos parece interesante señalar que en los últimos años ha resurgido un tipo de pintura figurativa realizada por una nueva generación de pintores, nacidos todos ellos en la segunda mitad del siglo XX, que buscan la representación de situaciones amenazantes o inquietantes y que plantean, desde claves pictóricas personales, una narrativa que gira en torno a lo oculto, a lo inhóspito y a lo absurdo.

Hablamos de un grupo de artistas que, sin intención premeditada, coinciden temporalmente en la utilización de un lenguaje figurativo para construir escenas que denotan una visión sombría y angustiante de la sociedad contemporánea y que ubican al espectador frente a un tipo de situación emotiva que bien podríamos identificar con la inquietante extrañeza freudiana. Un sentimiento que, según Freud «se da, frecuentemente y fácilmente, cuando se desvanecen los límites entre fantasía y realidad; cuando lo que habíamos tenido por fantástico aparece ante nosotros como real $\aleph^{3}$. Es decir, un sentimiento que aparece en el sujeto cuando lo que debería haber permanecido oculto se ha revelado, provocando, de este modo, una sensación de inquietud y espanto que vamos a poder localizar en los autores que aquí vamos a tratar.

Es significativo que desde el año 2013 se hayan organizado tres importantes exposiciones internacionales (Nightfall: New tendencies in figurative painting, This side of Paradise y New Black Romanticism) que han abordado este tema, hecho que demuestra el interés que están despertando este tipo de artistas y de poéticas por parte de los agentes del arte contemporáneo. Uno de los principales motivos de dicha tendencia podría residir en que, como señala Nicholas Royle, la propia existencia del ser humano en el mundo ha adquirido una connotación de inquietante extrañeza: a pesar de los avances científicos y tecnológicos que nos están posibilitando un mayor acercamiento a los secretos más íntimos de la existencia humana, estamos convirtiendo menos habitable el planeta, lo que provoca un aumento de la sensación de sufrimiento y de muerte en el sujeto contemporáneo ${ }^{4}$.

3 Freud, S., y Hoffmann, E.T.A. (1979). Lo siniestro - El hombre de la arena. (Trad. L. López Ballesteros y de Torres y C. Bravo-Villasante). Barcelona: José J. de Olañeta. (Original en alemán, 1919), 30.

4 Royle, N. (2003). The Uncanny. Manchester: Manchester University Press, 3. 
Hemos considerado oportuno partir de las tres exposiciones señaladas por varias razones. En primer lugar porque se trata de propuestas actuales que se han planteado en los últimos cinco años en torno a la temática que vamos a abordar y que nos han permitido nuevamente reflexionar desde distintas perspectivas sobre esos aspectos que definen el espacio narrativo señalado. Pero también, por considerar que, si por un lado, el proyecto New Black Romanticism abordaba un amplio espacio temporal que nos servía de punto de partida para comprender nuestro objeto de estudio desde una perspectiva histórica, por otro, las propuestas Nightfall y This side of Paradise era inevitable tenerlas en cuenta por presentar una selección de los artistas que mayor impacto han causado en la escena de la pintura figurativa contemporánea, muchos de ellos pertenecientes a la Escuela de Leipzig y a la Escuela de Cluj.

Pero además, estas exposiciones nos servían para constatar que aún en el año 2017 el número de mujeres representadas en propuestas de este tipo sigue siendo realmente escaso, lo que nos servía de ejemplo objetivo que corroboraba aquello que ya planteaba Linda Nochlin ${ }^{5}$ hace más de cuarenta años respecto a la omisión de la mujer en la historia del arte, un hecho que afortunadamente en los últimos años está siendo reivindicado por numerosas artistas y teóricas ${ }^{6}$. En este sentido, Patricia Mayayo apuntaba que las mujeres «se han visto abocadas a trabajar dentro de esa misma cultura pero ocupando una posición distinta a la de los artistas varones» ${ }^{7}$ debido a que sus propuestas artísticas no respondían al orden hegemónico establecido. $\mathrm{Y}$ es interesante señalar que esta situación se hace más notoria, si cabe, en el espacio específico que abordamos en este estudio dado que la pintura, al ser una disciplina tradicional, ha sido concebida y tratada desde sus inicios como una práctica masculina ${ }^{8}$. Es un hecho que tal jerarquía sexista sigue existiendo, aún se sigue cuestionando la capacidad de las mujeres para pintar. Como afirma Mayayo: «en el caso de las mujeres la equivalencia entre feminidad y baja calidad se establece automática e inmediatamente» ${ }^{9}$. Por esta razón, nuestro estudio parte de una reivindicación del trabajo de un grupo de mujeres artistas para crear una propuesta basada en una política de la igualdad. Pero no sólo lo hacemos en esta dirección sino que queremos constatar que sus propuestas divergen respecto al trabajo de los artistas varones incluidos en dichas exposiciones. Porque este trabajo nos ha permitido identificar otras aproximaciones a lo oculto, a lo inhóspito y a lo absurdo que, en este caso, son consecuencia de la situación psicológica y social de estas artistas. Por lo tanto, el objetivo de este artículo no se limita a dar visibilidad a un grupo de pintoras que están abordando dicho tema sino que, como señala Griselda Pollock, pretende aportar una interpretación basada en la desarticulación «de los discursos y prácticas de la propia historia del arte» ${ }^{10}$ con el fin de identificar relatos alternativos al canon establecido.

5 Nochlin, L. (1971). Why Have There Been No Great Women Artists?. Art News, 22-39; reimpresión en Nochlin, L. (1989). Women, Art and Power and Other Essays. Londres: Thames and Hudson (pp. 145-177).

6 Un estudio enormemente influyente para la crítica feminista y para lo que en este artículo se plantea: Pollock, G., y Rozsika, P. (1981). Old Mistresses. Women, Art, and Ideology. Londres: HarperCollins.

7 Mayayo, P. (2003). Historias de mujeres, historias del arte. Madrid: Cátedra, 52.

8 Sobre este tema, resulta muy sugerente el libro: Chadwick, W. (1999). Mujer, arte y sociedad. (Trad. M. Barberán). Barcelona: Destino. (Original en inglés, 1990). En él, la autora expone una serie de ejemplos sobre los diversos prejuicios de género que influyeron en la evaluación estética de obras pictóricas, concretamente en los casos de Marietta Robusti, Judith Leyster y las discípulas de Jacques-Louis David, entre otros.

9 Mayayo, P. op, cit, 40.

10 Pollock, G. (1988). Vision and Difference. Femininity, feminism and the histories of art. Londres y Nueva York: Routledge, 55. En Mayayo, P. (2003). Historias de mujeres, historias del arte. Madrid: Cátedra, 51. 
Así, nuestro artículo va a presentar la obra de diez pintoras figurativas que no han sido suficientemente representadas ni en las tres exposiciones señaladas ni en otras propuestas del circuito del arte contemporáneo oficial y que, por el hecho de trabajar en torno a esa inquietante extrañeza que antes mencionábamos, podrían haber formado parte de cualquiera de los proyectos expositivos antes citados.

Aunque el hecho de tratar a diez artistas en el espacio reducido de un artículo pueda parecer ambicioso, hemos preferido reducir la profundización de cada propuesta con el fin de que, dando visibilidad a un número mayor de ejemplos, este trabajo ofrezca una visión más amplia del problema y pueda servir al lector de punto de partida para futuras investigaciones. Con este fin, y para que la estructura del artículo ofrezca una mayor claridad, hemos agrupado las diez propuestas en tres bloques temáticos diferentes.

\section{Contexto}

\subsection{Nightfall: New tendencies in figurative painting}

La exposición Nightfall: New tendencies in figurative painting, comisariada por Jane Neal y presentada en 2013 en la Galerie Rudolfinum de Praga, se centraba en ese ámbito concreto de la pintura figurativa contemporánea que, como ya hemos indicado, situaba al espectador frente a atmósferas oscuras, inciertas y amenazantes.

Las obras presentadas en la exposición giraban en torno al título de la muestra, inspirado éste en el homónimo cuento de ciencia ficción que Isaac Asimov escribió en 1941 y en el que el autor planteaba las posibles situaciones y consecuencias que se darían en una sociedad sumergida en una prolongada noche.

En este sentido, incluía la obra de pintores como Justin Mortimer (1970), artista que aborda esta temática a través de un lenguaje pictórico que se mueve, como el mismo cuento, entre realidad y ficción, en un intento de retratar la violencia de lo social y, a la vez, la vulnerabilidad del ser humano, Tim Eitel (1971) que genera cierta angustia interior mediante la construcción de espacios que denotan la soledad y el aislamiento de un sujeto angustiado o Adrian Ghenie (1977) que se adentra en los abismos oscuros, nocturnos e insondables de la condición humana a través de sutiles estrategias formales que introducen al espectador en situaciones cargadas de tensión e incertidumbre.

Las obras de estos tres artistas citados nos pueden servir de ejemplo del tono poético que la exposición proponía y que, desde distintas claves pictóricas, desarrollaban el resto de los veintidós pintores internacionales que componían la selección. Tan sólo tres mujeres formaban parte de la muestra: Karin Mamma Andersson, Chantal Joffe y Caroline Walker, pintoras que analizaremos más adelante.

\subsection{This side of Paradise}

La exposición This side of Paradise que también fue comisariada por Jane Neal se inauguró en el año 2014 en la galería Sotheby's de Londres. Al igual que el proyecto expositivo anterior, esta muestra se centraba exclusivamente en la escena pictórica figurativa contemporánea más destacada. Sin embargo, en este caso la comisaria 
centraba su objetivo de forma más puntual, presentando una reflexión que se enfocaba sobre la idea de escena, de contexto, de entorno de un posible sujeto que busca ubicación en la sociedad contemporánea.

Así también, este proyecto enfatizaba el interés de los pintores propuestos por encontrar la belleza, incluso en las escenas más horribles y trágicas. A través de las pinturas seleccionadas, la comisaria planteaba un concepto intenso de belleza, familiar al que Eugenio Trías localizaba y que, según el autor, se daba cuando las categorías estéticas de lo bello y lo siniestro permanecían unidas. Recordemos que Trías en Lo bello y lo siniestro señalaba que «una de las condiciones estéticas que hacen que una obra sea bella es su capacidad por revelar y a la vez esconder algo siniestro» ${ }^{11}$. Esta idea de belleza, que ya fue denominada por los surrealistas como belleza convulsiva, Rosalind Krauss la relacionaba, atendiendo al ámbito de la fotografía surrealista, a una sensación que «hace temblar la seguridad del sujeto aportando una exaltación a través de un shock» ${ }^{12}$. El sentimiento que produce este tipo de belleza y que Krauss vincula a la inquietante extrañeza freudiana también es analizado por Hal Foster en Belleza compulsiva. En relación a ello, el autor señala que el espectador es seducido por una mezcla de deleite y de espanto, de atracción y de repulsión que desestabiliza al sujeto por su carácter irrepresentable e innombrable.

Las imágenes de los artistas Justin Mortimer, Tim Eitel y Adrian Ghenie que hemos visto, denotarían ese tipo de belleza oscura y trágica que Krauss, Foster y Trías analizaron y que Jane Neal proponía en este proyecto. Pero también el trabajo de Matthias Weischer (1973) y de Mircea Suciu (1978) son un buen ejemplo de ello. Si Weisher muestra espacios domésticos casi claustrofóbicos representados con cierta ambigüedad y extrañeza, Suciu hace visible una ansiedad existencial y un deseo de escapar a través de la representación de individuos que se asoman por agujeros en la pared o llevan la cabeza envuelta en telas.

En este proyecto se presentaron los trabajos de dieciséis artistas entre los cuales únicamente tres eran mujeres: Chantal Joffe y Caroline Walker, incluidas en la muestra anterior, y Rosa Loy que aparecía aquí por primera vez. Como ya hemos señalado, abordaremos el trabajo de estas artistas más adelante.

\subsection{New Black Romanticism}

La exposición New Black Romanticism, comisariada por Christoph Tannert, se presentó en el Museo Nacional de Arte de Rumania (MNAR) de Bucarest en mayo de 2017 y en la Künstlerhaus Bethanien de Berlín a finales del mismo año.

A diferencia de las exposiciones hasta ahora propuestas, esta muestra no se centraba sólo en el lenguaje pictórico sino que abordaba el mismo ámbito temático que estamos persiguiendo, relacionado con la oscuridad, la incertidumbre, la crueldad, etc., desde una perspectiva más amplia que abarcaba también otros soportes plásticos como la fotografía, el vídeo y la instalación.

Dicho proyecto expositivo se marcaba como punto de partida otra exposición titulada Dark Romanticism: From Goya to Max Ernst, comisariada por Felix Krämer

Trías, E. (2006). Lo bello y lo siniestro. Barcelona: Debolsillo, 80.

12 Krauss, R. (2002). Lo fotográfico. Por una teoría de los desplazamientos. (Trad. C. Zelich). Barcelona: Gustavo Gili S.A. (Original en inglés, 1990), 192. Para ampliar información véase: Krauss, R. (1997). Uncanny. En Bois, Y., y Krauss, R. (1997). Formless. A user's guide (pp. 192-197). Nueva York: Zone Books. 
y presentada en 2012 en el Städel Museum de Frankfurt y que serviría a Christoph Tannert de referente para la realización de su propuesta ${ }^{13}$.

Podría considerarse que Dark Romanticism: From Goya to Max Ernst es una de las exposiciones más ambiciosas que se han realizado en los últimos años en relación a la temática que estamos abordando. En ella se mostraba la obra de artistas europeos del movimiento romántico para hacer visible la posterior influencia que estos tuvieron en propuestas posteriores como el simbolismo y el surrealismo. El uso que el comisario Felix Krämer proponía de lo romántico no estaba relacionado con el sentimiento de una época histórica concreta sino, más bien, con un estado de la mente que da lugar a una visión del mundo percibido a través de un filtro de extrañeza, de oscuridad y de pérdida. Es decir, con aquellos tintes emocionales y poéticos a los que se habían dedicado los proyectos expositivos señalados anteriormente.

Entre los aspectos temáticos que se señalan en la exposición, y partiendo de la obra Nightmare (1781) de Henry Fuseli, destaca la alusión a la noche, a los sueños y a las pesadillas. Pero también se presenta a Goya con sus series Los Caprichos (1797-1799) y Desastres de la guerra (1810-1815) para hacer alusión a esa belleza que hemos visto que Krauss, Foster y Trías vinculaban a lo trágico y a lo horrible. Según Trías, el arte, desde el romanticismo, es impulsado por el deseo de dirigir al espectador hacia «un fondo selvático y abismal, de terror y de delicia, en donde se halla escondido el núcleo vital de lo humano, su núcleo arqueológico, ancestral, lo más íntimo a la vez que lo más secreto» ${ }^{14}$, es ahí donde el autor reconoce que reside la belleza, esa misma belleza que se relaciona al sentimiento de lo sublime y de lo siniestro y que alcanzaría su auge en el movimiento romántico, una belleza que sigue apareciendo en la pintura figurativa contemporánea y que, según Mario Praz, había tomado forma desde el momento en el que los artistas habían quedado seducidos por el horror: «el horror, como fuente de deleite y de belleza, terminó por actuar sobre el mismo concepto de belleza: lo horrendo» ${ }^{15}$.

También podemos constatar la escasa presencia de mujeres artistas presentadas en esta exposición. De un total de cien artistas representados sólo se incluye a Marie Čermínová (Toyen), pintora, dibujante e ilustradora checa, miembro del movimiento surrealista. Es incuestionable que tanto por la calidad de sus propuestas como por la cercanía temática, artistas como Remedios Varo, Alice Rahon, Maruja Mallo o Ángeles Santos, entre otras muchas mujeres pintoras, podrían haber formado parte de este proyecto. Sería muy interesante analizar con detenimiento la obra de estas artistas pero, por una cuestión de extensión de este artículo, sólo abordaremos la obra del grupo de pintoras figurativas contemporáneas que ya hemos mencionado.

Partiendo de esta experiencia, en la exposición New Black Romanticism, Tannert recuperaba esta propuesta con la intención de aportar nuevas lecturas al ámbito temático señalado, desde la complejidad de los lenguajes contemporáneos. Tannert afirmó que se trataba de «un espectáculo muy contemporáneo, ya que vivimos en un momento de miedo» ${ }^{16}$, esta declaración del comisario confirmaría aquella idea de

13 Aunque no se reconozca una influencia directa, también se pueden observar ciertas conexiones entre la propuesta Dark Romanticism: From Goya to Max Ernst y las exposiciones Nightfall y This side of Paradise aquí presentadas.

14 Trías, E. op. cit., 80.

15 Praz, M. (1999). La carne, la muerte y el diablo en la literatura romántica. (Trad. R. Mettini). Barcelona: El Acantilado. (Original en italiano, 1930), 69.

16 Tholund, S. (2017). Neue Schwarze Romantik. Kieler Nachrichten. Obtenido de http: //www.kn-online.de/Nachrichten/Kultur/Stadtgalerie-Kiel-Neue-Schwarze-Romantik [Consulta: 9 de diciembre de 2017]. Nota.- La 
Nicholas Royle que hemos señalamos anteriormente. En esta exposición se presentaba el trabajo de treinta y cuatro artistas internacionales donde sólo seis eran mujeres: Greta Alfaro (1977), Alexandra Baumgartner (1973), Susann Maria Hempel (1983), Lisa Junghanß (1971), Iris Van Dongen (1975) y Fabrizia Vanetta (1983). Dado que nuestro estudio se centra en el ámbito de la pintura figurativa contemporánea, cabría destacar a Iris Van Dongen y a Fabrizia Vanetta por ser ellas las únicas pintoras seleccionadas. Sin embargo, a pesar del tono tenebroso y enigmático de las imágenes de ambas artistas, en sus trabajos no llegamos a percibir con la misma intensidad ese ambiente de misterio, incomodidad y extrañeza que se puede advertir en las imágenes de las pintoras que vamos a analizar a continuación.

\section{Las mujeres que pintan}

Partiendo de esta realidad objetiva y siendo conscientes de la escasez de representación femenina en el ámbito del arte (en nuestro caso, de las tres exposiciones que hemos presentado sólo diez mujeres fueron presentadas de un total de cincuenta y nueve participantes), nuestra propuesta se centra en el estudio de diez pintoras figurativas contemporáneas que trabajan en torno a ese nudo emocional que habíamos relacionado con el concepto freudiano de inquietante extrañeza: cuatro pintoras que ya estaban incluidas en dichas exposiciones y seis propuestas más que resultan enormemente sugerentes respecto a la temática que estamos abordando. De esta manera, y como ya hemos manifestado, no sólo pretendemos denunciar la constante invisibilidad de la mujer artista que ya planteaba Linda Nochlin en 1971, sino descubrir otras formas de ver la realidad, y en concreto nuestra temática, que difieren de las propuestas planteadas por los artistas varones a los que hemos hecho alusión anteriormente. En este sentido, es oportuno destacar que las artistas que vamos a presentar a continuación parten de una apropiación de los discursos establecidos por la historia del arte y de las estructuras del pensamiento que rige en nuestra sociedad patriarcal para cuestionarlos desde un punto de vista feminista.

Aunque señalaremos estrategias propias de cada pintora en relación a la temática que proponemos, como adelantábamos en la introducción, hemos considerado oportuno estructurar este apartado en torno a tres bloques temáticos que atienden a la familiaridad poética entre las distintas propuestas y que ofrecen al lector una mayor claridad discursiva:

- La crisis interior y el deseo de armonía.

- La mujer como enigma y pesadilla.

- La identidad femenina y lo doméstico.

\subsection{La crisis interior y el deseo de armonía}

En este primer apartado presentamos la obra de Lynette Yiadom-Boakye (1977), Teodora Axente (1984) y Susanne Johansson (1969). Todas ellas elaboran unas imágenes que denotan cierta tensión social y una angustia existencial que se relaciona

cita del comisario, las declaraciones de las artistas y de algunos teóricos analizados en este estudio han sido traducidas por los autores de este artículo. Para ampliar información sobre este proyecto expositivo recomendamos el catálogo de la exposición: Tannert, C. (Ed.). (2017). New Black Romance. Berlín: Künstlerhaus Bethanien. 
con el miedo, la incertidumbre y cierta violencia sufrida pero que, a su vez, son capaces de transmitir un deseo de armonía entre el individuo y el entorno que le rodea. Desde este punto de vista, se podría considerar que las propuestas de estas artistas no se diferencian de las obras de los pintores a los que hemos hecho alusión anteriormente. Sin embargo, es obvio que el tono poético de sus trabajos es consecuencia de las dificultades y obstáculos a los que, como mujeres, han tenido que enfrentarse ya sea a nivel institucional como alegaba Linda Nochlin ${ }^{17}$, ya sea a nivel personal, como señalaba Germaine Greer en The Obstacle Race.

Así, consideramos que sus planteamientos parten de esta denuncia de la marginalidad y la discriminación de la mujer para plantear a través de códigos pictóricos personales cuestiones relacionadas con ciertos valores patriarcales establecidos que han vinculado, desde siempre, a la mujer con lo otro, atribuyéndole de este modo la condición de inferioridad con respecto al hombre (concebido como el yo). En este sentido, podríamos considerar que el grupo de artistas que presentamos en este bloque se rebelan contra este ego patriarcal haciendo visible, a través de sus propuestas pictóricas, la vulnerabilidad de dicha autoridad.
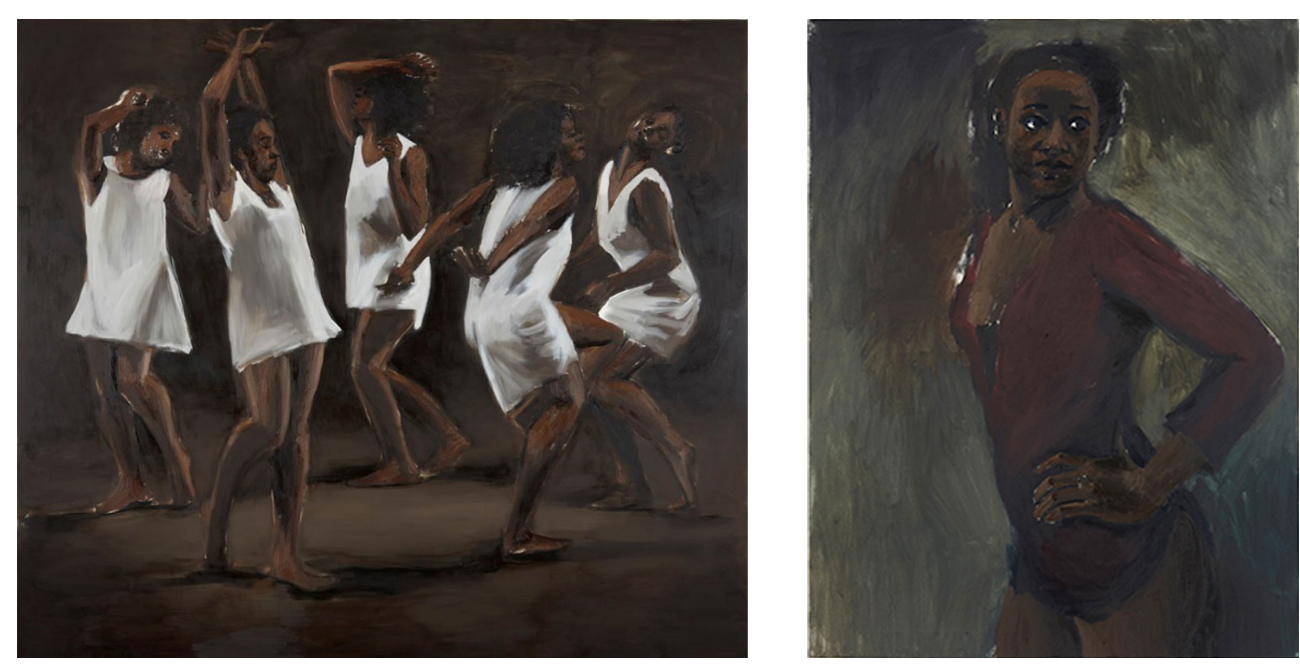

Fig. 1. Lynette Yiadom-Boakye, The Hours Behind You (2011), 98 x 118 cm., óleo sobre lienzo. Imagen disponible en la web de la galería Jack Shainman

Fig. 2. Lynette Yiadom-Boakye, Quiet challenges (2012), 51 x 39 cm., óleo sobre lienzo. Imagen disponible en la web de la galería Jack Shainman

Lynette Yiadom-Boakye retrata figuras de raza negra (ella es de ascendencia ghanesa) pero su preocupación no reside tanto en la identidad racial como en los sentimientos que transmite la interacción de esos personajes con el ambiente en el que están representados (Fig. 1 y Fig. 2). En palabras de la artista, los sujetos representados «no comparten nuestras preocupaciones o ansiedades. Están en otro lugar completamente diferente $\rangle^{18}$.

Véase la nota 5.

18 Shainman, J. (s.f.). Lynette Yiadom-Boakye. Nueva York: Jack Shainman Gallery. Obtenido de http: //www. jackshainman.com/artists/lynette-yiadom-boakye/ [Consulta: 29 de enero de 2018]. Para ampliar información 
En efecto, podemos observar que los rostros de las personas que figuran en sus obras poseen un carácter aparentemente apacible, se muestran inmersos en sus propios pensamientos o actividades, ajenos al entorno y a las circunstancias que les rodean. Sin embargo, si atendemos al espacio oscuro en el que están representados estos personajes, podemos observar, como señala la artista, «un tipo de violencia a su alrededor que ellos manifiestan $\rangle^{19}$. Es a través de este ambiente pesado que contrasta con el estado de las figuras donde se puede percibir ese conflicto al que estamos haciendo alusión y que Yiadom-Boakye recrea mediante la representación de los personajes y el lugar en el que han sido ubicados.
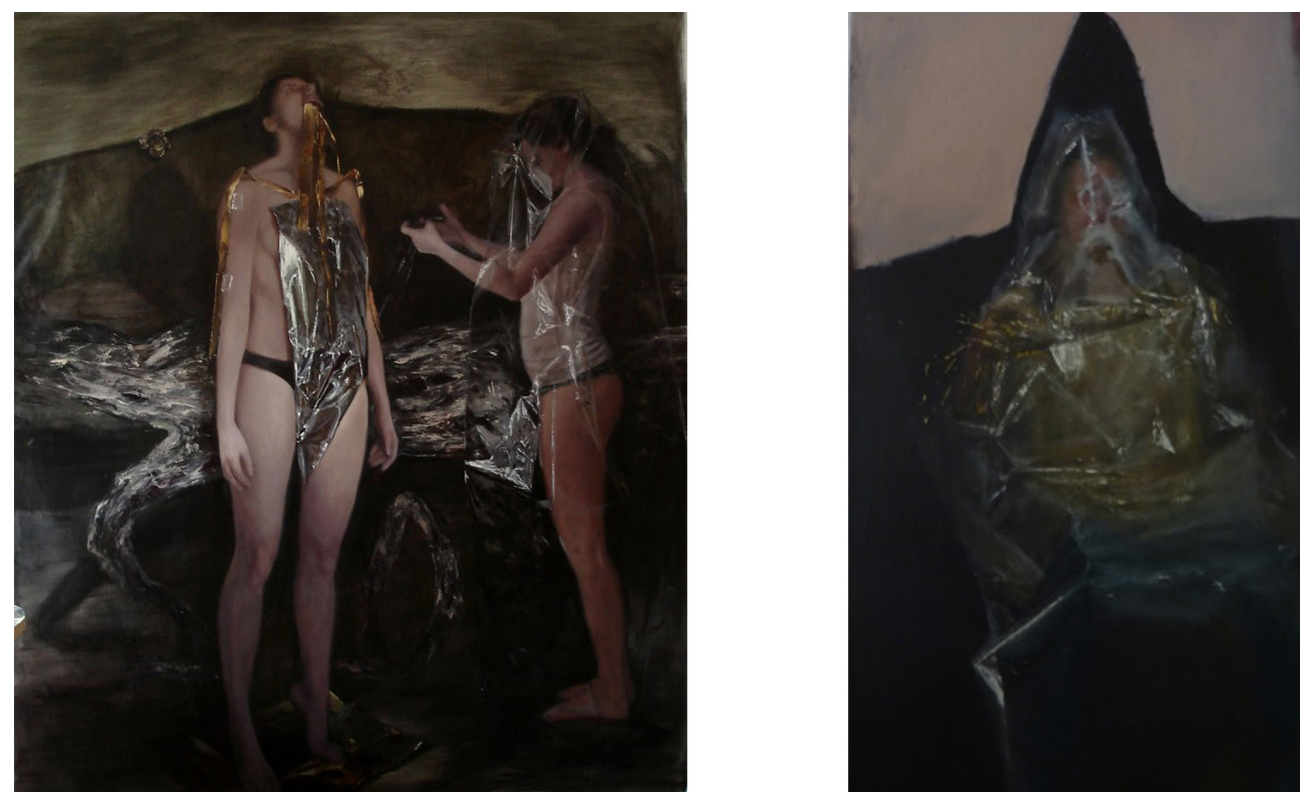

Fig. 3. Teodora Axente, Diana Denial (2014), 236 x 199 cm., óleo sobre lienzo. Imagen disponible en la web de la galería Doris Ghetta

Fig. 4. Teodora Axente, John the baptist I (2015), 43 x $23 \mathrm{~cm}$., óleo sobre lienzo. Imagen disponible en la web Artsy

Teodora Axente plantea esta tensión desde una perspectiva diferente a la de Yiadom-Boakye. En las obras de Axente lo que atrae la mirada del espectador es la representación de materiales de aluminio que envuelven parte del cuerpo de los personajes (Fig. 3 y Fig. 4). Las figuras de sus cuadros se muestran ensimismadas en la realización de actividades inusuales: «mis personajes crean un mundo de absurdos y no tratan de ofrecer una clave de interpretación, sino más bien tratan de dejar que el espectador interprete $»^{20}$, argumenta la artista.

sobre la artista recomendamos: Schwabsky, B. (2011). Vitamin P2: new perspectives in painting (pp. 324-327) Londres: New York: Phaidon.

19 Valli, M., y Dessanay, M. (2014). A brush with the real: figurative painting today, Londres: Laurence King, 218.

20 Beligar, C. (2016). Teodora Axente, artist plastic: „Nu trebuie să încercăm să fim toți Adrian Ghenie sau Victor Man”. Transilvania Reporter. Obtenido de http: //transilvaniareporter.ro/cultura/teodora-axente-artist-plasticnu-trebuie-sa-incercam-sa-fim-toti-adrian-ghenie-sau-victor-man/ [Consulta: 12 de febrero de 2018]. 
Pero si atendemos a las inquietudes de Axente, observamos que estos individuos parecen estar esperando una conexión con ese otro mundo espiritual: «me gusta ahondar en la dualidad entre el cuerpo y el alma, pero el exterior habla más del interior ${ }^{21}$. Es interesante recordar que esa idea de reflejar lo invisible a través de lo visible es heredera de la tradición romántica: «cierra tu ojo corporal de modo que primero puedas ver tu cuadro con tu ojo espiritual» ${ }^{22}$, recomendaría Caspar David Friedrich. En este caso, apreciamos cómo Axente parte de esa estela que se dibujaba en la exposición Dark Romanticism: From Goya to Max Ernst y que, como vemos, llega ahora a una generación de artistas más jóvenes. Sin embargo, a diferencia de éstos, la artista plantea la dualidad interior/exterior como algo que está en el espacio de lo indeterminado, próximo al que Julia Kristeva hacía referencia cuando afirmaba que «al reconocer nuestra inquietante extrañeza, no sufriremos ni gozaremos de ella desde fuera. Lo extraño está en mí, por tanto todos somos extranjeros. Si yo soy extranjera, no hay extranjeros» ${ }^{23}$. Kristeva plantea esta cuestión para hacer referencia a ese ego patriarcal que sitúa a la mujer como lo otro y, en este sentido, ofrece una interpretación de las imágenes de Axente, de esos personajes situados en un espacio indefinido, donde los límites entre el yo y lo otro se disipan.

Esta dualidad entre interior y exterior que impulsa el trabajo de Teodora Axente se cristaliza en las obras de Susanne Johansson. Algunas de sus obras más sugerentes están compuestas por arboledas donde, a menudo, encontramos la presencia de una figura solitaria que entabla un diálogo aparentemente apacible con el entorno (Fig. 5). Cuando observamos esta serie de pinturas de Johansson podríamos considerar que son una especie de reinterpretación de los paisajes invernales y desolados elaborados por el mismo Friedrich. En concreto, el título de una de sus últimas exposiciones A Room Within (2015), podría hacer alusión a esa idea de escena que nace del interior y que nos remite a las palabras de Schelling cuando afirma que «el arte figurativo está situado como vínculo activo entre el alma y la naturaleza y sólo puede concebirse en el medio viviente entre ambas ${ }^{24}$. No obstante, como en las pintoras anteriores, el trabajo de Johansson se distancia del discurso romántico y de las propuestas de los artistas a los que hemos hecho alusión. Por ejemplo, en la obra Between all and nothing (2015) (Fig. 6) podemos observar un bosque y en un segundo plano una figura que parece femenina. A pesar de las connotaciones tenebrosas que puede adquirir el bosque, Johansson representa la escena con cierta tranquilidad, pudiéndose percibir esa unión anhelada entre individuo y naturaleza. Pero también, desde el punto de vista en el que estamos abordando este apartado, la representación de la naturaleza, del bosque y de su carácter ancestral, puede remitirnos a una época mítica en la que no se había instalado esa diferencia entre el yo y lo otro que proponía Kristeva.

21 Ibid

22 Friedrich, C. D. (1968). Briefen und Bekenntnissen. Berlin: Sigrid Hinz, 94. En Krämer, F. (Ed.). (2012). Dark Romanticism: From Goya to Max Ernst. Ostfildern: Hatje Cantz, 131.

23 Kristeva, J. (1988). Etrangers á nous-meches. Paris: Gallimard (colección Folio/Essais). En Kristeva, J., y Vericat. I. (1996). Freud: "heimlich/ unheimlich", la inquietante exrañeza. Debate Feminnista, 13, 367.

24 Schelling, F. (1963). La relación de las artes figurativas con la naturaleza. (Trad. A. Castaño Piñán). Buenos Aires: Aguilar. (Original en alemán, 1807), 42. 

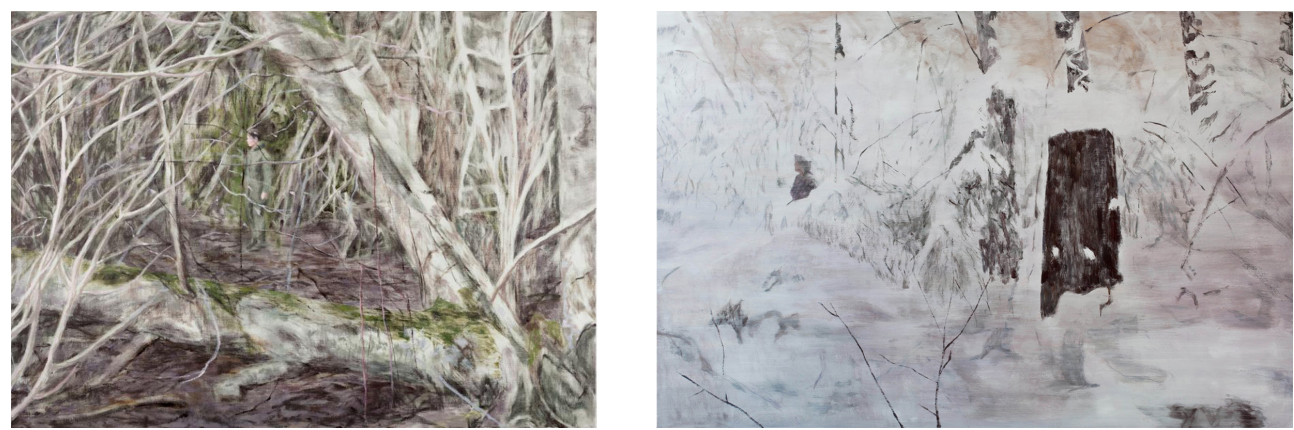

Fig. 5. Susanne Johansson, Trespasses (2018), 105 x $140 \mathrm{~cm}$, óleo sobre lienzo. Imagen disponible en la web de la galería Magnus Karlsson

Fig. 6. Susanne Johansson, Between all and nothing (2015), 80 x 122 cm., óleo sobre tabla. Imagen disponible en la web de la galería Magnus Karlsson

\subsection{La mujer como enigma y pesadilla}

Si en el apartado anterior nos hemos ocupado de esa condición de otredad que la sociedad patriarcal le ha otorgado a la mujer, en este apartado vamos a tratar las propuestas de tres pintoras, Oda Jaune (1979), Rosa Loy (1958) y Elly Strik (1961) que parten de un tipo de discurso en el que se vincula a la mujer con lo misterioso y lo terrorífico, con la belleza y el horror. Nos referimos a las múltiples representaciones que se han realizado a lo largo de la historia del arte, especialmente en la segunda mitad del siglo XIX, y que relacionaban la figura de la mujer con características monstruosas y amenazantes (las brujas, las diabólicas o la femme fatale serían ejemplos de ello). Mario Praz señala el vínculo que ya establecieron algunos artistas románticos entre la sexualidad femenina y las supersticiones del horror y del $\mathrm{mal}^{25} \mathrm{y}$ que utilizaron como fuente de inspiración. En este sentido, no podemos olvidar que Freud en Lo siniestro también relacionaba esa inquietante extrañeza con la sexualidad femenina y la muerte, todo ello haciendo referencia a aquella belleza convulsiva que señalábamos anteriormente y que Hal Foster lo vinculaba a una mezcla de ese deleite y de espanto que se produce en el sujeto ante un mal que le ataca. Para Foster, el placer negativo que produce este tipo de imágenes es representado en el surrealismo a través de atributos femeninos, como si se tratase de «una intuición de la pulsión de muerte, recibida por el sujeto patriarcal al mismo tiempo como una promesa de éxtasis y como una amenaza de extinción ${ }^{26}$. Como consecuencia de todo esto, las artistas que presentamos en este bloque parten de dicha iconografía con el fin de denunciar el pensamiento misógino que ha dominado en la historia del arte ${ }^{27}$. Sus obras podrían considerarse como una reivindicación de la mujer como sujeto a través de lo misterioso, lo extraño o lo inquietante pero que hace visible su autonomía y se

25 Praz, M. op.cit, 69.

26 Foster, H. (2008). Belleza Compulsiva. (Trad. T. Stuby). Buenos Aires: Adriana Hidalgo. (Original en inglés, 1993), 79.

27 Para ampliar información sobre este tema recomendamos los siguientes ensayos:

Pedraza, P. (1991). La Bella, enigma y pesadilla. Barcelona: Tusquets.; Dijkstra, B. (1994). Ídolos de la perversidad: la imagen de la mujer en la cultura de fin de siglo. (Trad. V. Campos González). Madrid: Debate. (Original en inglés, 1986); Bornay, E. (2008). Las hijas de Lilith. Madrid: Cátedra. 
opone a esa mirada masculina que presenta a la mujer como un objeto siniestro. Las imágenes de este grupo de pintoras, como si se tratase de pesadillas, ocultan en su seno una tensión que sumerge al espectador en una turbadora ficción cuando éste la percibe como real.

El trabajo de Oda Jaune, apoyándose en escenas de contenido erótico, llega a rozar lo demoníaco y lo espantoso. En la obra Twosome (Fig. 7) observamos en un primer plano una figura femenina que, como indica el título, parece entablar una relación con la figura del mono representada en un segundo plano. En este caso, el diálogo que se produce entre las dos figuras hace alusión a una insatisfacción interna como consecuencia de una oposición respecto a ciertos valores establecidos por la sociedad. Al definir su trabajo, Jaune afirma: «pinto emociones, luchas, estructuras de poder y sentimientos interiores ${ }^{28}$. Pero la obra de Jaune no reside sólo en una manifestación de dicha inquietud sino que, frente a ese mono que observa, la artista está reivindicando su poder y sabiduría como mujer. Estas ideas se traducen en el resto de sus obras a través de escenas pobladas de seres deformados que habitan con vísceras y elementos fálicos, creando un ambiente que se percibe como familiar y extraño a la vez (Fig. 8). Su amplia iconografía es representada mediante unos códigos formales que provocan en el espectador sentimientos encontrados de repulsión y de atracción.
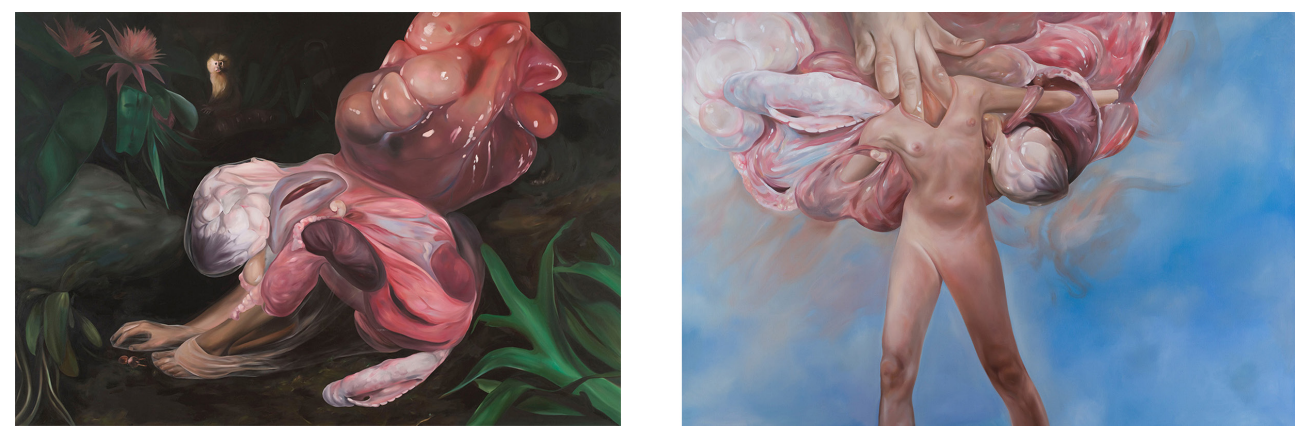

Fig. 7. Oda Jaune, Twosome (2012), 190 x 280 cm., óleo sobre lienzo. Imagen disponible en la web de la artista

Fig. 8. Oda Jaune, Être chairs (2013), 190 × 280 cm., óleo sobre lienzo. Imagen disponible en la web de la artista

En un ambiente entre el sueño y la vigilia, similar al de Jaune, se colocan las figuras femeninas representadas por Rosa Loy. Sin embargo, a diferencia de los personajes de la artista anterior, las mujeres que Loy incorpora dentro de un mundo que recuerda a los cuentos de hadas, son rotundas y fuertes, tanto a nivel simbólico como a nivel formal (Fig. 9 y Fig. 10). Recordemos que la exposición ya mencionada This side of Paradise, en la que Loy era una de las pocas mujeres incluidas, pretendía presentar a un grupo de pintores cuyas imágenes mostraban ese tipo de belleza negativa a la que hemos hecho alusión anteriormente. En el caso de Loy, esto se consigue desde una perspectiva feminista, construyendo imágenes oníricas que ocultan elementos narrativos perturbadores y que giran en torno a su experien-

28 Valli, M., y Dessanay, M. op. cit, 164. 
cia como mujer en una sociedad patriarcal. En sus obras, la artista crea un mundo exclusivamente femenino, mostrando esa parte que siempre queda oculta, al margen, con el fin de reivindicar la igualdad en un mundo dominado por hombres. Así, en muchas de sus obras se puede observar la figura del doppelgänger, un término alemán inventado por Jean-Paul Richter alrededor de 1796 y desarrollado, desde el punto de vista del psicoanálisis, por Otto Rank ${ }^{29}$. La palabra doppelgänger proviene de doppel que significa "doble" y gänger traducido como "andante" y hace referencia a la imagen desdoblada del yo en un individuo externo ${ }^{30}$. En el caso de Loy, la figura del doppelgänger hace alusión a un reflejo de ella misma y de la feminidad colectiva.
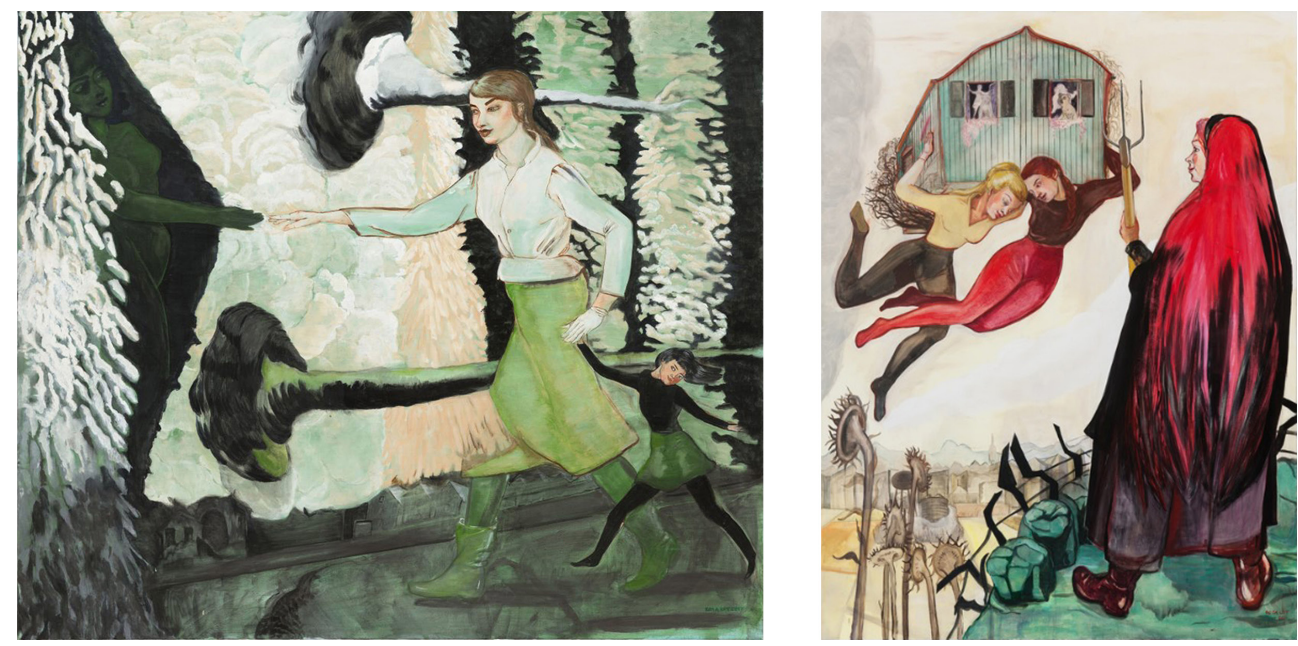

Fig. 9. Rosa Loy, Mut (2017), 110 x 130 cm., caseína sobre lienzo.

Imagen disponible en la web de la galería Baton

Fig. 10. Rosa Loy, Saat des schweigens (2012), 170 x 130 cm., caseína sobre lienzo.

Imagen disponible en la web de la artista

En este bloque temático también merece especial atención la artista Elly Strik que, partiendo de la observación de su propio cuerpo, pretende eliminar toda referencia a la identidad, provocando, de este modo, ese aspecto recóndito y perturbador que estamos sondeando. En su exposición Fantasmas, novias y otros compañeros, presentada en el Museo Reina Sofía de Madrid en el año 2014, Strik ofrecía un imaginario personal a través de la representación de velos, máscaras, cráneos o marañas de pelo, todo ello formalmente desvanecido y pintado con lápiz y óleo de una forma extremadamente sutil (Fig. 11). La artista suele utilizar este tipo de recurso técnico porque le otorga a la imagen un carácter espectral, fantasmagórico, febril. Este balanceo entre el velar y el desvelar que caracteriza su obra, y que en cierta medida también se puede observar en algunas de las artistas aquí tratadas,

29 Rank, O. (1914). Der Doppelgänger: Eine psychoanalytische Studie. Viena: Internationaler Psychoanalytischer Verlag.

30 Para ampliar información sobre este tema recomendamos: Bargalló, J. (Ed.) (1994). Identidad y alteridad: aproximación al tema del doble. Sevilla: Alfar. Así como los estudios citados de Sigmund Freud y Nycholas Royle. 
es una invitación a que el espectador se adentre en lo que está oculto, secreto y es desconocido para incitar al descubrimiento del rastro visible que remite a un enigma inabarcable.

Quisiéramos prestar especial atención a su obra 1773-2013 (Fig.12), incluida en dicha exposición, donde observamos un retrato cuyo rostro está oculto tras un velo. En un primer momento, se podría considerar que es un rostro de mujer ya que el bordado del velo hace alusión a esa idea de lo femenino. Sin embargo, si nos fijamos en el título de la obra y atendemos a las influencias artísticas de Strik, nos lleva a sospechar que se trata de una reinterpretación que la artista ha realizado de un autorretrato de Goya de 1773. A través de esta práctica, Strik mezcla en una misma imagen lo masculino y lo femenino en un intento de dispersar la identidad. Sería sugerente señalar, en relación a esta propuesta de Strik, la exposición Inside the Visible. An elliptical Traverse of 20th Century Art. In, of, and from the feminine presentada en el Institute of Contemporary Art de Boston en 1986. En ella, se reunió la obra de más de treinta mujeres artistas cuya práctica se asentaba, entre otras cuestiones, en una ruptura de los fundamentos patriarcales del género establecido $^{31}$.
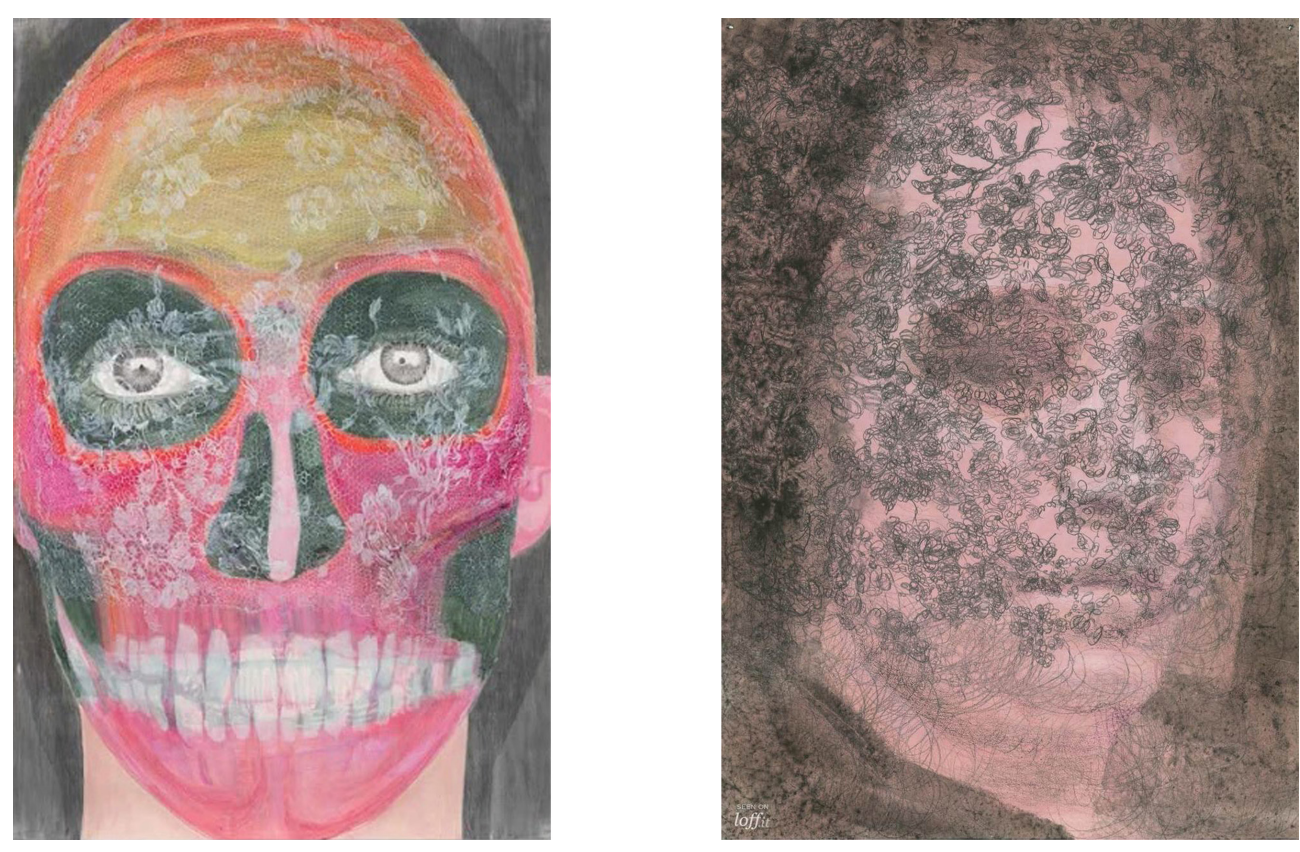

Fig. 11. Elly Strik, Beaucoup de fleurs (2013), 240 x 160 cm., lápiz de color, grafito, óleo y laca sobre papel. Imagen disponible en la web Hoyesarte

Fig. 12. Elly Strik, 1773-2013 (2013), 42 x 29.7 cm., lápiz de color, grafito, óleo y laca sobre papel. Imagen disponible en la web del Museo Reina Sofía

31 Para ampliar información, véase: Pollock, G. (1996). Inscripciones en lo femenino. En A. M. Guasch, (Ed.). Los manifiestos del arte posmoderno, 1980-1995: textos de exposiciones 1980-1995 (pp. 322-346). Madrid: Akal. 


\subsection{La identidad femenina y lo doméstico}

En este último apartado vamos a presentar el trabajo de cuatro pintoras que centran su interés en el tema de la identidad femenina y de lo doméstico. Si el análisis de las obras de las artistas que hemos propuesto hasta el momento nos habían hecho reflexionar sobre la misoginia que ha dominado en la historia y se nos había invitado a desarticular esa condición de otredad o de objeto siniestro que le ha sido otorgado a la mujer, los trabajos de Claire Tabouret (1981), Chantal Joffe (1969), Caroline Walker (1982) y Karin Mamma Andersson (1962) que ahora proponemos van a ofrecer una perspectiva crítica sobre la marginalidad de la mujer y los estereotipos y convenciones establecidos por la sociedad patriarcal. Sus obras cuestionan tanto la vinculación de la mujer a lo doméstico como los ideales del canon de belleza que la sociedad capitalista contemporánea le impone con todas sus fuerzas.

El trabajo de Claire Tabouret surge de la búsqueda de su propia identidad, tema que aborda mediante la elaboración de retratos de niñas, jóvenes y mujeres adultas en diferentes situaciones. Es interesante destacar cómo en una de sus exposiciones presentada en Parvis en 2015 y titulada Duel au soleil, la artista presentaba un conjunto de figuras femeninas con pose y vestimentas marciales junto a retratos de mujeres enmascaradas que mostraban únicamente los ojos y la boca. Recordemos que ese uso de la máscara para la representación de la mujer lo hemos señalado también en el trabajo de Elly Strik como alusión a lo oculto, al interior, a lo desconocido. Sin embargo, en el caso de Tabouret, el uso de este elemento adquiere además un sentido político de poder y de lucha.
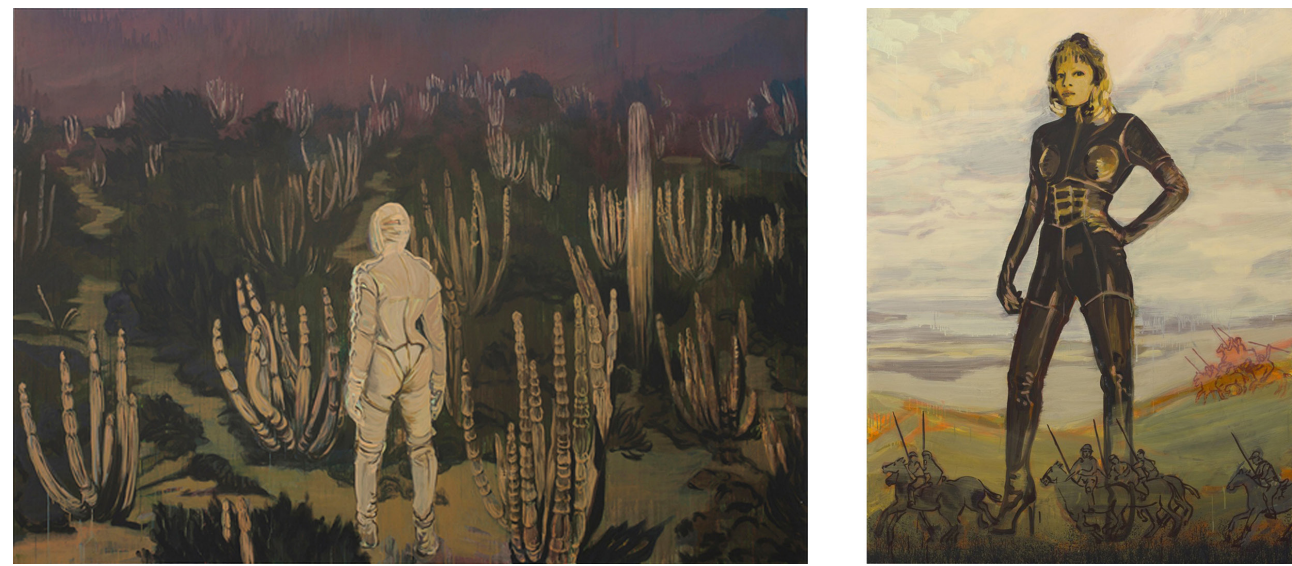

Fig. 13. Claire Tabouret, In search of the new land (2015), $230 \times 330 \mathrm{~cm}$., acrílico sobre lienzo. Imagen disponible en la web de la galería Bugada \& Cargnel

Fig. 14. Claire Tabouret, Batteground (2016), 220 x $170 \mathrm{~cm}$., acrílico sobre lienzo. Imagen disponible en la web de la galería Bugada \& Cargnel

En dicha exposición se presentó una pintura de gran formato titulada In search of a new land (2015) (Fig. 13) en la que la artista representaba un paisaje desértico repleto de cactus y envuelto en una atmósfera oscura y difusa. Una figura femenina, vestida con un traje ajustado que envolvía completamente su cuerpo, daba la espalda 
al espectador dirigiendo su mirada hacia un horizonte que parecía no tener fin. Es evidente la referencia textual al héroe romántico, inconformista, viajero, encarado a lo ignoto que tantas veces Caspar David Friedrich representaría y que Rafael Argullol en La atracción del abismo relaciona con la necesidad de superar los límites. Pero lo interesante de esta imagen es que la heroína es una mujer dispuesta a tomar el protagonismo y ocupar el rol que le corresponde en la historia del arte. Este gesto que nos ofrece la artista acerca del protagonismo de la mujer se desarrolla ampliamente en la serie titulada Battleground (2016) (Fig. 14). La narrativa que Tabouret lleva a cabo en ambas series pictóricas, no debería interpretarse únicamente como un enfrentamiento a ese carácter marginal de la mujer como señalaba Nochlin ${ }^{32}$, sino como una crítica de la representación canónica donde la artista abre un debate sobre ciertos mitos establecidos en la historia del arte.

El trabajo de Chantal Joffe también se ocupa de la identidad a través de la representación de mujeres, sean de su círculo familiar o sacadas de Internet. Los cuadros de Joffe están trabajados a través de pinceladas enérgicas y fluidas que contrastan con la actitud aparentemente tranquila que adoptan las mujeres retratadas. La tensión entre la cotidianidad de la escena y la distorsión formal de su tratamiento transmite al espectador cierta sensación de incomodidad. A través de este procedimiento, la artista ha elaborado numerosas series pictóricas sobre mujeres que han quedado al margen de la historia. Un ejemplo de ello es la exposición que realizó en el año 2011 en la galería Victoria Miro de Londres. Las obras que componían la muestra aludían a Emily Brönte, Emily Dickinson, Lee Krasner, Tamara de Lempicka o Susan Sontag, mujeres con las que la artista se siente identificada o cuya historia le ha impactado. Joffe decidió, intencionadamente, no titular ninguna de estas obras para remarcar la invisibilidad y la ausencia de protagonismo de las mujeres en los relatos históricos. Además de ello, la artista elaboró los cuadros con una paleta de tonos oscuros e incorporó la figura de la sombra en la pintura dedicada a Susan Sontag para enfatizar dicho asunto (Fig. 15). El interés de este proyecto pictórico se basa en poner en tela de juicio, desde una perspectiva de género, las bases de esa jerarquía que aún prevalece en la sociedad actual.

Es necesario también hacer alusión a sus autorretratos desnudos (Fig. 16), estas obras transmiten una aparente naturalidad al ver representada la figura de la artista pensativa y ensimismada. Sin embargo, como en el resto de su trabajo, algunas partes de su cuerpo suelen estar distorsionadas, otorgándole a la obra un carácter más inquietante y provocador ${ }^{33}$. En este sentido, la artista reconoce que se siente más honesta cuando pinta su propio cuerpo porque para ella «hay un gran placer en describir cosas que otras personas encontrarían realmente horribles» ${ }^{34}$. Lo que la artista plantea con este tipo de imágenes es

32 Nochlin, L. op. cit., 176.

33 Sería interesante señalar en relación a este tipo de imágenes el estudio realizado por Mike Kelley en Playing with dead things. The Uncanny publicado en 1993, donde el autor presta especial interés a un conjunto de obras que parten de la representación del cuerpo para suscitar esa sensación de inquietante extrañeza a través de una serie de características estéticas. Sin embargo, debido a que este artículo se centra en el ámbito de la pintura contemporánea y en que nuestro objetivo se aleja de lo planteado por Kelley, no consideramos oportuno desarrollar esta propuesta.

34 Artist interview: oil paints with Chantal Joffe (2016). Cass Art. Obtenido de https: //www.cassart.co.uk/blog/ interviewchantaljoffe.htm [Consulta: 1 de febrero de 2018]. 
una desarticulación de los ideales de belleza propuestos por la sociedad así como una denuncia a la representación del cuerpo femenino como objeto que han desarrollado los hombres a lo largo de la historia del arte. De acuerdo con esto, no es de extrañar que cuando el espectador se enfrenta al trabajo de esta artista experimente un sentimiento en el que, como observaba Umberto Eco, «el rechazo de la deformidad va acompañado de éxtasis decadentes ante las más seductoras violaciones de todos los cánones clásicos» ${ }^{35}$.
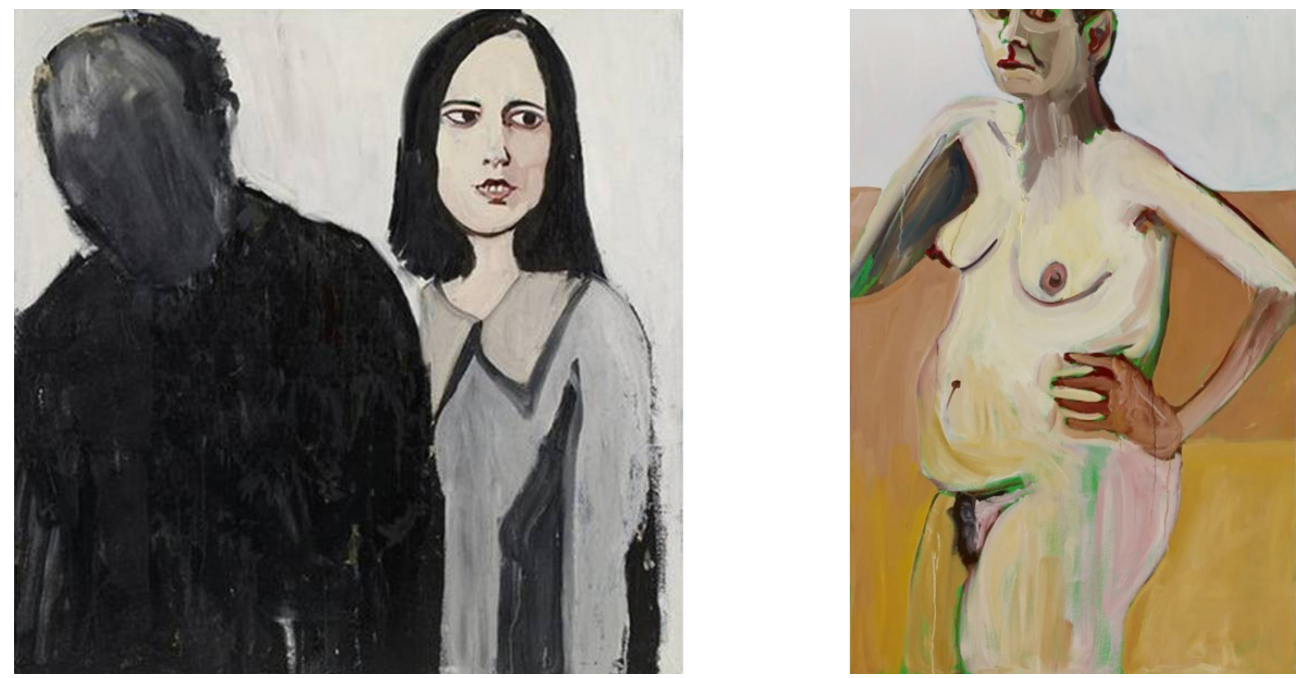

Fig. 15. Chantal Joffe, Untitled (2010), 138 x 183.5 cm., óleo sobre lienzo. Imagen disponible en la web Artmap

Fig. 16. Chantal Joffe, Self-portrait with hand on hip (2014), 183 x 122.5 cm., óleo sobre lienzo. Imagen disponible en la web de la galería Victoria Miro

Pero el ámbito de la identidad y del espacio de lo cotidiano ha sido abordado también desde puntos de vista que se alejan de las propuestas hasta aquí presentadas. Es el caso de Caroline Walker y de Karin Mamma Andersson, artistas cuyo interés no reside tanto en la representación del cuerpo sino en la elaboración de imágenes relacionadas con el espacio doméstico y con objetos que aluden tradicionalmente a la mujer.

La obra de Caroline Walker gira en torno al tema del hogar. En este sentido, la artista apunta: «uso la pintura para reflexionar sobre cómo vivimos nuestras vidas en espacios privados y cómo lo doméstico puede convertirse en un escenario para el desempeño de los arquetipos de la feminidad» ${ }^{36}$. Si en el trabajo de Tabouret percibíamos una crítica a esa ausencia de mujeres como heroínas y guerreras en las representaciones pictóricas

35 Esta reflexión de Umberto Eco aparece en la contraportada del libro: Eco, U. (2007). Historia de la fealdad. (Trad. M. Pons Irazazábal). Barcelona: Lumen. (Original en italiano, 2007). El análisis que realiza Eco en este libro parte de su estudio: Eco, U. (2004). Historia de la belleza. (Trad. M. Pons Irazazábal). Barcelona: Lumen. (Original en italiano, 2004).

36 Valli, M., y Dessanay, M. op. cit, 229. Para ampliar información sobre la artista véase: Melick, T. (Ed.). (2016). Vitamin P3: new perspectives in painting (pp. 316-319) Londres; New York: Phaidon. 
realizadas por los artistas a lo largo de la historia, en la obra de Walker observamos un interés por tratar otro de los tópicos presentes en las pinturas elaboradas por los hombres a lo largo de los siglos: la representación de la mujer dentro del espacio doméstico. Esta preocupación de la artista surge del deseo de «volver a evaluar esto en un contexto contemporáneo y a través de una mirada femenina $\rangle^{37}$.

El interés de Walker queda reflejado en su trabajo: sus obras se caracterizan por la representación de una presencia femenina, por lo general solitaria, dentro de un hogar lujoso (Fig. 17 y Fig. 18). El tratamiento pictórico de estos espacios provoca cierta tensión ya que la artista, en vez de representarlos con el aspecto acogedor que debería tener un entorno cotidiano y familiar, los elabora mediante una atmósfera dura y una gama cromática que transmite cierta incomodidad e inseguridad del espacio representado. Asimismo, la relación que se crea entre la mujer y el hogar es igualmente inquietante ya que la artista la representa ajena a ese entorno que le rodea y que delata su falta de libertad. Además, esa extrañeza se potencia por el hecho de situar al espectador en la posición de un voyerista.
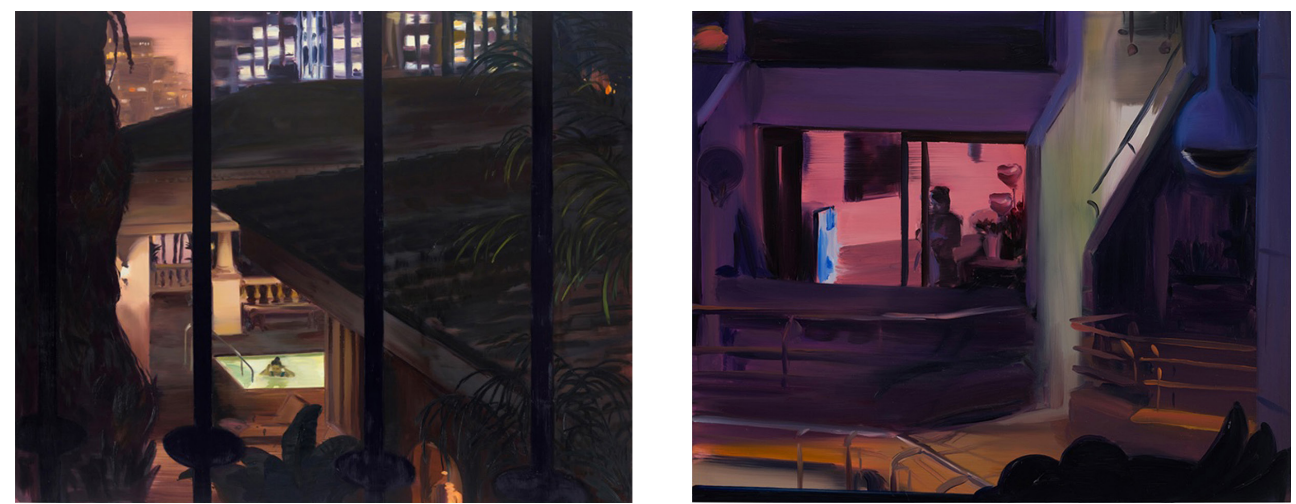

Fig. 17. Caroline Walker, Hot tub (2017), 200 x 250 cm., óleo sobre lienzo. Imagen disponible en la web de la artista

Fig. 18. Caroline Walker, Rear Windows (2017), 45 x 55 cm., óleo sobre lienzo.

Imagen disponible en la web de la artista

En determinados trabajos, Karin Mamma Andersson también reflexiona acerca de la relación entre la mujer y el hogar, aunque la artista no sólo fija su interés en este vínculo sino que aborda otros aspectos más amplios igualmente relacionados con la mujer y el concepto de lo doméstico desde un punto de vista crítico. Un ejemplo de ello es la exposición Behind the curtain presentada en la galería David Zwirner de Nueva York en el año 2015. A través de diversos símbolos asociados a la feminidad como corsés, casas de muñecas, espacios domésticos, labores del hogar, etc, Andersson apunta que su exposición trata de las «ideas sociales sobre cómo se espera que sea una mujer» ${ }^{38}$. De este modo, la artista abre un debate sobre los fundamentos patriarcales y el canon establecido en la historia del arte. Todas las obras de la expo-

Ibid., 229.

38 Parkes, O. (2016). Imagining Women's Lives in Painted Dreams. Vice. Obtenido de https: //broadly.vice.com/ en_us/article/jpyyb7/imagining-womens-lives-in-painted-dreams [Consulta: 5 de febrero de 2018]. 
sición forman una especie de escenario teatral donde predomina una paleta sombría y donde se combina un juego marcado de luces y de sombras que le ofrece a la exposición una atmósfera inquietante.

Dos piezas realizadas sobre la pared de la galería destacan por su gran tamaño. En una de ellas se muestra a una mujer vestida de época que parece que acaba de tender la ropa, quedando paralizada frente al espectador. La otra pieza (Fig. 19) nos resulta más sugerente por su misterio: en ella se puede observar una figura representada de espaldas al espectador y agarrada a una barra que está sujeta por dos columnas. Lo que inquieta de la imagen es la gran sombra de su figura proyectada sobre la pared. El uso de este elemento ya lo habíamos encontrado en la obra de Joffe cuando aludía a la situación social de la mujer e intuimos ahora que en la pintura de Mamma Andersson esa sombra también podría adquirir el mismo significado. La misma idea aparece en otra obra en la que muestra dos figuras femeninas representadas con aspecto de maniquíes y que hace alusión a esa idea de mujer pasiva y sumisa que el patriarcado ha impuesto (Fig. 20). De acuerdo con todo esto, se podría considerar que esta exposición es una invitación de la artista a indagar en la oscuridad con el fin de desarticular los roles y estereotipos que aún prevalecen en la sociedad actual.
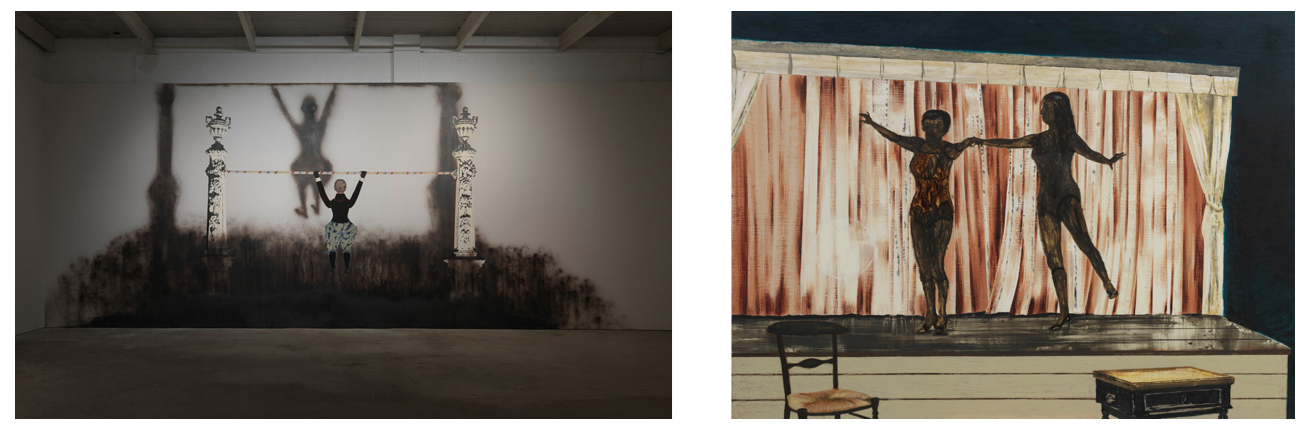

Fig. 19. Karin Mamma Andersson, Behind the curtain (2015), vista de la instalación. Imagen disponible en la web de la galería David Zwirner

Fig. 20. Karin Mamma Andersson, Behind the curtain (2014), 121.9 x 166.7 cm., óleo sobre lienzo. Imagen disponible en la web Wall Street International

\section{A modo de conclusión}

Este estudio no pretende ser más que una invitación a indagar en lo que queda en la sombra. Como nuestras artistas, nos hemos ocupado de dar visibilidad a aquello que tantas veces queda silenciado a la sombra de los discursos imperantes. Así también, hemos pretendido ofrecer una perspectiva crítica feminista respecto a los cánones establecidos por la sociedad y la historia del arte, tal y como estas artistas hacen patente a través de su trabajo pictórico.

Aunque por razones de extensión no hemos podido profundizar tanto como hubiésemos deseado en el trabajo de estas diez mujeres, nuestros objetivos se han centrado en dar visibilidad a un número considerable de artistas que, desde la práctica 
pictórica y a través de diferentes estrategias, están llevando a cabo una desarticulación de los roles y estereotipos impuestos por el sistema patriarcal con el propósito de establecer una revisión de conciencia. Consideramos esta propuesta como una aproximación parcial a un trabajo de investigación más extenso que realizaremos en un futuro próximo.

Sirva nuestra pequeña aportación como apoyo a estas pintoras que, desarrollando su lenguaje desde una perspectiva crítica feminista, y frente a los excesos de la cultura patriarcal, invitan a la deconstrucción de conceptos ideológicos y éticos ligados al género y siguen trabajando en esos márgenes injustos y hostiles en los que la sociedad las ha ubicado históricamente. 